\title{
ACTIVE POST-OPERATIVE PHONED SEARCH FOR LATE INFECTIONS OF SURGICAL SITE AND THROMBOEMBOLIC EVENTS IN THE LATE POSTOPERATIVE PERIOD OF PLASTIC SURGERIES IN A DAY HOSPITAL IN THE MUNICIPALITY OF PORTO ALEGRE
}

\author{
Diana Rodrigues Nicoletti ${ }^{1}$, Dionísia Oliveira de Oliveira ${ }^{2}$, \\ Stefania Giotti Cioato ${ }^{3}$, Morgana Thais Carollo Fernandes ${ }^{1}$
}

\begin{abstract}
Introduction: Elective and plastic surgical procedures are normally considered safer than emergency surgeries, although they cause concern to health services. The aim of this study was to analyze the active phoned search as a screening instrument for the diagnosis of surgical site infection (SSI) and thromboembolic events (TEs) in the late postoperative care of plastic surgeries in a private day hospital in the city of Porto Alegre.
\end{abstract}

Methods: Quantitative, descriptive, retrospective, cross-sectional study. Data was collected from a database provided by phoned active search of sign and symptoms for epidemiological monitoring by the control infection service of a day-hospital, from July 2015 to February 2017.

Results: A total of 3.595 patients were effective contacted in the indicated period. Among these patients, $77.6 \%$ received guidance on TEs. Moreover, $0.4 \%$ and $0.2 \%$ of patients reported signs and symptoms of SSI and TE, respectively. Associated procedures caused $50.0 \%$ of SSIs and $87.5 \%$ of TEs. Phoned search increased in $0.2 \%$ the number of reported cases of both adverse events in the overall sample.

Conclusion: SSI and TE are worrying events for health institutions, since they can put patient safety at risk. Therefore, the data obtained in this study were used as a basis to qualify phoned search as an effective screening instrument for SSI and TE and provided support for the development of more consistent phoned search mechanisms for monitoring these postoperative events.

Keywords: Epidemiological surveillance; infections; thromboembolism; plastic surgery

The World Alliance for Patient Safety (WAPS) highlights the need for practices to ensure patient safety and prevent potential damage caused by adverse events ${ }^{1}$, defined as events or circumstances that may result or resulted in unnecessary damage to the patient ${ }^{2}$. According to the IT Department of the Brazilian Unified Health System (DATASUS), 739,867 adverse events and/or technical complaints from outpatient clinics, i.e., equipment failure that directly or indirectly affected care provision, were reported in Brazil in 2017, 95.8\% of which occurred in the southeast region of the country, $1.6 \%$ in the south region, and $2.5 \%$ in the other regions ${ }^{3}$. Such events may be related to the increased number of plastic surgeries worldwide, as demonstrated in a report issued by the International Society of Aesthetic Plastic Surgery revealing that, in 2013, 23 million plastic surgeries were performed worldwide. The leading country in the number of surgeries is Brazil, where 1,491,721 more surgeries were performed than in the USA ${ }^{4}$.

One of the most common AEs are surgical site infections (SSI), which are those manifesting within the first 30 days after surgery or after 1 year after surgeries for placement of prostheses. SSIs are classified according to the
Clin Biomed Res. 2018;38(2):99-104

1 Curso de Enfermagem, Centro Universitário Ritter dos Reis - UniRitter. Porto Alegre, RS, Brasil.

2 Serviço de Controle de Infecção Hospitalar, Hospital Giovanni Battista. Porto Alegre, RS, Brasil.

3 Programa de Pós-Graduação em Ciências Biológicas: Farmacologia e Terapêutica. Universidade Federal do Rio Grande do Sul (UFRGS). Porto Alegre, RS, Brasil.

Corresponding author: Diana Rodrigues Nicoletti diana.nicoletti@hotmail.com Centro Universitário Ritter dos Reis (UniRitter)

Rua Orfanotrófio, 555 90840-440, Porto Alegre, RS, Brasil. 
affected site, and prophylactic antibiotic therapy is recommended to start within the first 2 days after progression of symptoms, regardless of whether SSI is confirmed by medical diagnosis 5 . These events represent a potential public health problem leading to increased patient's length of hospital stay and thus generating higher costs and increasing morbidity and mortality ${ }^{5,6}$.

Patient care indicators show that $1,084,604$ nosocomial infections were reported in Brazil in 2017, 98.6\% of which occurred in the southeast region of the country, $0.1 \%$ in the south region, and $1.3 \%$ in the other regions ${ }^{7}$. In addition to SSIs, thromboembolic events (TEs) are another $A E$ that cause concern to hospital teams and are considered risk factors for worse prognosis in surgical patients. There is little evidence on TEs following plastic surgeries. Schwartzman et al. ${ }^{8}$ found that one TE occurs every 50,000 plastic surgeries, two thirds of which result in death.

TEs are caused by the formation and migration of blood clots within deep veins. These events are usually asymptomatic and are difficult to diagnose clinically. However, in case of suspected TE, best medical practices recommend requesting imaging studies, such as color Doppler ultrasound, computed tomography angiography, or radiography, to establish the diagnosis ${ }^{9}$. It has been known that SSI and TEs are a potential problem of public health, since the Brazilian Ministry of Health reported a mortality rate of $3.25 \%$ for these events in private health facilites ${ }^{10}$. Thus, health care professionals are required to identify both TE and SSI.

Within this context, the Brazilian National Health Surveillance Agency (Agência Nacional de Vigilância Sanitária, ANVISA) establishes that epidemiological surveillance measures should be implemented by Hospital Infection Control Service (Serviço de Controle de Infecção Hospitalar, SCIH) of each hospital ${ }^{11}$. Surveillance of surgical patients may be performed through surveys at surgical outpatient clinics, phoned searches, or written questionnaires, depending on the institution's profile ${ }^{12}$.

Therefore, the aim of this study was to analyze the use of active phoned search as an instrument for the diagnosis of SSIs and TEs in the late postoperative period of plastic surgeries, considering the difficulties in implementing phoned search and the scarcity of scientific findings on the use of this method for epidemiological surveillance. Additionally, this study aims to provide support for the development of more consistent phoned search mechanisms for monitoring the above postoperative events.

\section{METHODS}

This is a quantitative, descriptive, retrospective, cross-sectional study with a document search approach. The present study was conducted in an outpatient private hospital in the city of Porto Alegre, southern Brazil, which performs reconstructive aesthetic procedures.

Data were obtained from a database including information on an active phoned search for epidemiological surveillance undertaken by the $\mathrm{SCIH}$ of the coparticipating institution from July 2015 to February 2017. Phone calls were made 30 days after surgery. Data were recorded on a standardized instrument including patient clinical data, recommendations and prophylactic guidelines on SSI and TE, tabulated on Excel spreadsheets, and expressed as absolute and relative frequencies.

The present study was conducted according to ethical regulations for human subjects research set forth in the Brazilian National Health Council Resolution no. $466 / 12$ and was approved by the Research Ethics Committees of Centro Universitário Ritter dos Reis and the coparticipating institution under Consolidated Opinion no. 2.343.604. The involved researchers are committed to ensure data confidentiality.

\section{RESULTS}

A total of 5,531 patients who underwent surgical procedures during the study period were selected for the phoned search. Of these, 65\% (3595) were effectively contacted, $34.6 \%(1,916)$ were unable to be contacted, and $0.4 \%$ (22) had not a registered telephone number. Among those who were effectively contacted, $77.2 \%(2,777)$ received guidance on postoperative TEs, $0.4 \%$ (16) had suspected SSI, and $0.2 \%(8)$ had suspected TE, as shown in Table 1.

Table 2 describes the characteristics of patients with suspected SSI. Of these, $87.5 \%$ (14) presented with signs and symptoms of SSI, $81.3 \%$ (13) received a prescription for prophylactic antibiotics, but SSI was confirmed in $50 \%$ (8) of patients.

Associated surgeries, i.e., undergoing more than one surgical procedure, accounted for $50 \%$ (8) of SSIs. An analysis of bacterial growth revealed that growth of methicillin-sensitive Staphylococcus aureus (MSSA) was observed in $75 \%$ (3) of patients who had biological material - surgical wound (SW) cultures - collected by the primary physician, as shown in Table 3.

Finally, it is worth mentioning that, differently from SSI, only one patient with signs and symptoms of TE were not diagnosed with thromboembolism but reported to have received treatment for pulmonary thromboembolism (Table 4). 
Table 1: Population profile of the study sample.

\begin{tabular}{|c|c|c|c|c|c|c|c|c|c|}
\hline \multirow{3}{*}{ Sex } & \multirow{3}{*}{$\begin{array}{c}\text { Female } \\
\text { Male }\end{array}$} & \multicolumn{2}{|c|}{2015} & \multicolumn{2}{|c|}{2016} & \multicolumn{2}{|c|}{2017} & \multicolumn{2}{|c|}{ Overall } \\
\hline & & 1,242 & $96.57 \%$ & 2019 & $97.68 \%$ & 237 & $97.90 \%$ & 3,498 & $97.38 \%$ \\
\hline & & 44 & $3.42 \%$ & 48 & $2.32 \%$ & 5 & $2.07 \%$ & 97 & $2.60 \%$ \\
\hline Single procedure & & 748 & $58.16 \%$ & 1,213 & $58.68 \%$ & 147 & $60.74 \%$ & 2,108 & $59.20 \%$ \\
\hline Associated procedures & & 538 & $41.84 \%$ & 854 & $41.32 \%$ & 95 & $39.25 \%$ & 1,487 & $40.80 \%$ \\
\hline Guidance on TE & Yes & 1,134 & $77.41 \%$ & 1,477 & $77.33 \%$ & 178 & $80.91 \%$ & 2,789 & $78.55 \%$ \\
\hline prophylaxis & No & 350 & $23.58 \%$ & 433 & $22.67 \%$ & 42 & $19.09 \%$ & 825 & $21.78 \%$ \\
\hline Suspected SSI & & 3 & $0.23 \%$ & 10 & $0.48 \%$ & 3 & $1.24 \%$ & 16 & $0.65 \%$ \\
\hline Suspected TE & & 2 & $0.15 \%$ & 3 & $0.15 \%$ & 1 & $0.41 \%$ & 6 & $0.24 \%$ \\
\hline
\end{tabular}

Associated procedures: those with incisions to more than one site. Guidance on TE prophylaxis: Moving lower limbs with the patient in the sitting or lying position. SSI: surgical site infection; TE: thrombotic event.

Table 2: Cases of suspected surgical site infection reported in post-discharge surveillance by phoned search.

\begin{tabular}{lccc}
\hline & & Absolute number & Relative number \\
\hline Sex & Female & 16 & $100.0 \%$ \\
Single procedure & & 7 & $43.8 \%$ \\
Associated procedures & & 9 & $56.3 \%$ \\
Signs of SSI & Yes & 14 & $87.5 \%$ \\
& No & 2 & $12.5 \%$ \\
Suture dehiscence & Yes & 6 & $37.5 \%$ \\
& No & 10 & $62.5 \%$ \\
Time until disease occurrence & Before 15th postoperative day & 9 & $56.2 \%$ \\
& After 15th postoperative day & 7 & $43.8 \%$ \\
Reintervention & Yes & 6 & $37.5 \%$ \\
& No & 10 & $62.5 \%$ \\
Recommendation for prophylactic ABT & Yes & 13 & $81.3 \%$ \\
International Classification of Diseases & No & 3 & $18.8 \%$ \\
code T81: Complications of procedures, & SSI & 8 & $50.0 \%$ \\
not elsewhere classified & Seroma & 6 & $37.5 \%$ \\
& Inflammatory process & 1 & $6.3 \%$
\end{tabular}

Single procedure: those with incisions to one site. Associated procedures: those with incisions to more than one site. Reintervention: seek for medical and hospital care. ABT: antibiotic therapy; SSI: surgical site infection.

Table 3: Confirmed cases of SSI reported in post-discharge surveillance by phoned search.

\begin{tabular}{lccc}
\hline & & Absolute number & Relative number \\
\hline Sex & Female & 8 & $100.0 \%$ \\
Single procedure & & 4 & $50.0 \%$ \\
Multiple procedures & Yes & 4 & $50.0 \%$ \\
Signs of SSI & No & 8 & $100.0 \%$ \\
& Yes & 0 & $0.0 \%$ \\
Suture dehiscence & No & 1 & $12.5 \%$ \\
& Bth postoperative & 7 & $87.5 \%$ \\
Time until disease & day & 5 & $62.5 \%$ \\
occurrence & Before & 3 & $37.5 \%$ \\
Reintervention & Yfter 15th postoperative day & 4 & $50.0 \%$ \\
Recommendation for & No & 4 & $50.0 \%$ \\
prophylactic ABT & Yes & 8 & $100.0 \%$ \\
Collection of cultures & No & 0 & $0.0 \%$ \\
Microorganism & Yes & 4 & $50.0 \%$ \\
& No & 4 & $50.0 \%$ \\
\hline
\end{tabular}

Single procedure: those with incisions to one site. Multiple Procedures: those with incisions to more than one site. Reintervention: seek for medical and hospital care. ABT: antibiotic therapy; MSSA: methicillin-sensitive Staphylococcus aureus; SSI: surgical site infection. 
Table 4: Cases of suspected TEs reported in post-discharge surveillance by phoned search.

\begin{tabular}{|c|c|c|c|}
\hline & & Absolute number & Relative number \\
\hline Female & & 8 & $100.0 \%$ \\
\hline Single procedure & & 1 & $12.5 \%$ \\
\hline Associated procedures & & 7 & $87.5 \%$ \\
\hline \multirow[t]{2}{*}{ Guidance of TE prophylaxis } & Yes: & 7 & $87.5 \%$ \\
\hline & No & 1 & $12.5 \%$ \\
\hline Signs of TE & Yes & 8 & $100.0 \%$ \\
\hline \multirow{2}{*}{$\begin{array}{l}\text { Time until disease } \\
\text { occurrence }\end{array}$} & Before 15 th postoperative day & 5 & $62.5 \%$ \\
\hline & After 15 th postoperative day & 3 & $37.5 \%$ \\
\hline \multirow[t]{2}{*}{ Seek for medical assistance } & Yes & 8 & $100.0 \%$ \\
\hline & No & 0 & $0.0 \%$ \\
\hline \multirow[t]{4}{*}{ Imaging tests } & Doppler ultrasound & 4 & $50.0 \%$ \\
\hline & Doppler ultrasound + radiography & 2 & $25.0 \%$ \\
\hline & Computed tomography angiography & 1 & $12.5 \%$ \\
\hline & $\begin{array}{l}\text { Computed tomography angiography + } \\
\text { radiography }\end{array}$ & 1 & $12.5 \%$ \\
\hline \multirow[t]{2}{*}{ Hospitalization } & Yes & 4 & $50.0 \%$ \\
\hline & No & 4 & $50.0 \%$ \\
\hline \multirow{4}{*}{$\begin{array}{l}\text { International Classification } \\
\text { of Diseases code 182: Other } \\
\text { venous embolism and } \\
\text { thrombosis }\end{array}$} & Deep vein thrombosis & 5 & $57.1 \%$ \\
\hline & Pulmonary thromboembolism & 1 & $14.3 \%$ \\
\hline & Pulmonary embolism & 1 & $14.3 \%$ \\
\hline & No diagnosis & 1 & $14.3 \%$ \\
\hline
\end{tabular}

Single procedure: those with incisions to one site. Associated procedures: those with incisions to more than one site. TE: thromboembolic events.

\section{DISCUSSION}

Study results show a predominance of females $(97.3 \% ; 3,498)$ and presence of signs and symptoms of SSI (87.5\%; 14 out of 16 patients with suspected SSI) and TE (100\%; 8 patients with suspected TE). We observed that the disease occurred before the 15th operative day in $56.2 \%$ (9 out of 16 ) of patients with suspected SSI and in $62.5 \%$ (5 out of 8 ) of patients with suspected TE. Rates of suspected SSI ( $0.4 \% ; 16$ out of 3595$)$ and TE $(0.2 \% ; 8$ out of 3595$)$ observed after phoned search were low, which may be explained by the fact that only $65 \%$ of patients were effectively contacted.

These findings increase concern with patient safety, since SSIs and TEs are known to be major hospital problems, because of their high incidence and significant impact on patients, leading to health complications, increased length of hospital stay, and death ${ }^{5,12-14}$. Some factors may contribute to infectious and thromboembolic processes, such as operative time, number of incisions, use of prosthesis, and patient-specific characteristics ${ }^{5,12-16}$. Associated procedures accounted for $50 \%$ (4 out of 8 ) of SSIs and $87.5 \%$ ( 7 out of 8 ) of TEs, which corroborated other studies that assessed the prevalence of SSI and TEs in multiple clean surgeries using a post-discharge search approach $^{16-18}$. Studies conducted in the states of São
Paulo, Distrito Federal, and Minas Gerais found that most signs and symptoms of SSI manifested before the 15th postoperative day, confirming results from the present study, which found that $62.5 \%$ of cases of suspected SSI occurred during this period ${ }^{17,19,20}$.

With regard to microbial analysis of SW cultures, our results are consistent with those of a retrospective study conducted by Batista and Rodrigues ${ }^{16}$ in 2012 showing that MSSA was the predominant microorganism in SSI (40.4\%). This germ predominantly colonizes the skin and may be originated from the patient him/herself, the surgical team, and/or the environment (including surgical material)5,15,16. Current studies on techniques for post-discharge search are in line with a retrospective study conducted by Klein et al. which concluded that there is no gold standard method for the surveillance of SSIs. Thus, SCIHs are recommended to assess the most appropriate surveillance approach according to their realities ${ }^{12-14,16,17,19,21-23}$.

In the present study, outpatient follow-up through phoned search increased in $0.2 \%$ the number of reported SSI (8 out of 3,595$)$ and TE ( 7 out of 3,595$)$. Such findings are consistent with those of another study that found lower SSI rates in clean outpatient surgeries $^{22}$. In line with our results, a study by Oliveira in the state of Minas Gerais, Brazil, reported that $53 \%$ of the sample were effectively contacted ${ }^{19}$ 
vs. $65.0 \%$ in the present study. It is worth noting that the process of surveillance is essential to increase accuracy, achieve more reliable indicators, and reduce underreporting ${ }^{17,18,20}$. Phoned search is a low cost and easy to perform method with importance on health care services and patient safety ${ }^{12,13,20}$. However, the low rates of effective contact reported in different studies result in a significantly reduced sample, especially if phone calls are made during business hours.

Additionally, diagnosis sensitivity is a key point in this method, since the patient is a layperson who may provide a doubtful description of SW leading to overreporting, in addition to the risk of recall bias $^{12,13,17,19}$. It should be reaffirmed that there is no single standard method for the surveillance of SSI; however, regardless of the method, diagnostic criteria for SSI established by ANVISA should be met ${ }^{11-14,16,17,19-21}$. Additionally, SCIHs should include search for TEs in their postoperative follow-up strategy, because of its high mortality rate and involvement

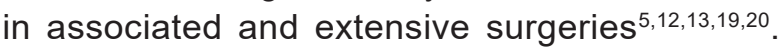
In order to improve care practices and institutional indicators and to solve the scarcity and/or absence of studies on post-discharge search, further studies are recommended to assess the implementation of different methods and their results in the active search aimed at controlling SSIs and TEs. Finally, it was possible to meet the objective of the present study, since the use of active phoned search as a screening method to diagnose SSIs and TEs has some limitations, such as the low number of effective contacts, but is an excellent method, considering the profile of the coparticipating institution, which can yield more reliable indicators and improve the care processes.

\section{Conflicts of Interest}

The authors declare no conflicts of interest.

\section{REFERENCES}

1. Brasil. Ministério da Saúde. Agência Nacional de Vigilância Sanitária (ANVISA). Investigação de eventos adversos em serviços de saúde. Brasília: ANVISA; 2013.

2. World Health Organization (WHO). World alliance for patient safety: forward programe 2008-2009. Geneva: WHO; 2008.

3. Brasil. Ministério da Saúde. DATASUS. Sistema de Informações Ambulatoriais do SUS (SAI/SUS). Investigação de eventos adversos e/ou queixas técnicas. Brasília: DATASUS; 2017.

4. Sociedade Brasileira de Cirurgia Plástica (SBCP). De acordo com a ISAPS, Brasil lidera ranking de cirurgias plásticas no mundo. São Paulo: SBCP; 2014. [cited 2016 Nov 21]. Available from: http://www2. cirurgiaplastica.org.br/de-acordocom-a-isaps-brasil-lidera-ranking-decirurgias-plasticas-no-mundo/

5. Prates CG, Stadñik CM. Segurança do paciente, gestão de riscos e controle de infecções hospitalares. 1. ed. Porto Alegre: Moriá; 2017.

6. Zimlichman E, Henderson D, Tamir $\mathrm{O}$, Franz C, Song P, Yamin CK, et al. Health care-associated infections: a meta-analysis of costs and financial impact on the us health care system. JAMA Intern Med. 2013;173(22):203946. http://dx.doi.org/10.1001/ jamainternmed.2013.9763. PMid:23999949.

7. Brasil. Ministério da Saúde. DATASUS. Sistema de Informações Ambulatoriais do SUS (SAI/SUS). Investigação de surtos em serviços de saúde. Brasília: DATASUS; 2017.

8. Schwartzman UP, Batista KT, Duarte LTD, Saraiva RÂ, Fernandes MBC. Complicações anestésicas em Cirurgia Plástica e a importância da consulta pré-anestésica como instrumento de segurança. Rev Bras Cir Plást. 2011;26(2):221-7. http://dx.doi.org/10.1590/S198351752011000200007.

9. Sociedade Brasileira de Angiologia e Cirurgia Vascular (SBACV). Trombose venosa profunda. Radiol Bras. 2002;35(1):62. http://dx.doi.org/10.1590/S010039842002000100020.

10. Brasil. Ministério da Saúde. DATASUS. Sistema de Informações Ambulatoriais do SUS (SAI/SUS). Taxa de mortalidade em setor privado. Brasília: DATASUS; 2007.
11. Brasil. Ministério da Saúde. Agência Nacional de Vigilância Sanitária (ANVISA). Critérios diagnósticos de infecção relacionada à assistência à saúde. Brasília: ANVISA; 2013.

12. Oliveira AC, Ciosak SI, D'Lorenzo C. Vigilância pós-alta e o seu impacto na incidência da infecção de sítio cirúrgico. Rev Esc Enferm USP. 2007;41(4):6539. http://dx.doi.org/10.1590/ S0080-62342007000400016. PMid:18193621.

13. Oliveira AC, Ciosak SI. Infecção de sítio cirúrgico em hospital universitário: vigilância pósalta e fatores de risco. Rev Esc Enferm USP. 2007;41(2):25863. http://dx.doi.org/10.1590/ S0080-62342007000200012. PMid:17722392.

14. Keyes GR, Singer R, Iverson RE, Nahai F. Incidence and predictors of venous thromboembolism in abdominoplasty. Aesthet Surg J. 2018;38(2):162-73. http://dx.doi. org/10.1093/asj/sjx154.

15. Brasil. Ministério da Saúde. Agência Nacional de Vigilância Sanitária (ANVISA). Critérios diagnósticos de infecção relacionada à assistência à saúde. Brasília: ANVISA; 2017. 
16. Batista TF, Rodrigues MCS. Vigilância de infecção de sítio cirúrgico pós-alta hospitalar em hospital de ensino do Distrito Federal, Brasil: estudo descritivo retrospectivo no período 2005-2010. Epidemiol. Serv. Saúde. 2012;21(2):253-64.

17. Lima CA, Souto CF, Gonçalves RPF, Torre RM. Taxa de Infecção de Sítio Cirurgico na Maternidade: o impacto da busca pós-alta. Rev Enferm UFPE on line. 2014;8(Suppl 1):2397-405.

18. Winocour J, Gupta V, Kaoutzanis C, Shi H, Shack RB, Grotting $\mathrm{JC}$, et al. Venous thromboembolism in the cosmetic patient: analysis of 129,007 patients. Aesthet Surg J. 2017;37(3):337-49. PMid:28207041.
19. Oliveira AC, Lima BAG. Vigilância pósalta dos pacientes cirúrgicos: métodos recomendados e a experiência de um hospital universitário. Rev Min Enf. 2004;8(3):409-13.

20. Ribeiro JC. Análise da ocorrência e dos fatores predisponentes de infecção de sítio cirúrgico em pacientes submetidos a cirurgias ortopédicas [dissertação]. Ribeirão Preto: Universidade de São Paulo; 2012.

21. Chor D, Klein $\mathrm{CH}$, Marzochi KBF. Infecção hospitalar: comparação entre dois métodos de vigilância epidemiológica. Cad Saude
Publica. 1990;6(2):201-17. http:// dx.doi.org/10.1590/S0102-

311X1990000200008.

22. Martins MA, França E, Matos JC, Goulart EM. Vigilância pós-alta das infecções de sítio cirúrgico em crianças e adolescentes em um hospital universitário de Belo Horizonte, Minas Gerais, Brasil. Cad Saude Publica. 2008;24(5):1033-

41. http://dx.doi.org/10.1590/ S0102-311X2008000500010. PMid:18461232.

23. Brasil. Ministério da Saúde. Portaria $\mathrm{n}^{\circ} 2616$, de 12 de maio de 1998. Diário Oficial da União. 1998 Maio 12.

Received: Feb 5, 2018 Accepted: Apr 22, 2018 